\title{
Building Favorite School Character Through Self- Evaluation of Emi Models
}

\author{
Subangun ${ }^{1}$, Laily Isroin ${ }^{2}$ \\ English Department, Faculty of Teacher Training and Education, Universitas Muhammadiyah \\ Ponorogo, Indonesia ${ }^{1}$ \\ Nursing Department, Faculty of Health Sciences, Universitas Muhammadiyah Ponorogo, \\ Indonesia $^{2}$ \\ \{pak.b.jozz@gmail.com ${ }^{1}$, lailyisroin@ymail.com $\left.{ }^{2}\right\}$
}

\begin{abstract}
One of the excellent school characters is having a focused and specific work plan. To prepare a targeted and specific work plan, accurate data on the non-achievement of targets in the national school standard are required. In this connection requires self-evaluation of the school. During this time the entire school has done self-evaluation online. However, many obstacles faced by the school. For that, we need a breakthrough self-evaluation EMI Model. EMI or Evaluation Internal Quality is an internal quality evaluation model developed by the Human Resources Development Agency for Education and Quality Assurance for Education Quality Assurance Center (BPSDMP-PMP) which has been implemented in LPTK. EMI is a systemic activity of inherent quality educational quality assurance (internally driven), to oversee the continuous improvement of school education. EMI schools have so many advantages that they need to be implemented across all primary schools. With the implementation of the EMI Model's self-evaluation, the school can provide a rapid, precise, and focused work plan. As a result, the time required for repair is relatively fast. And ultimately, schools that implement self-evaluation EMI models become excellent school characters.
\end{abstract}

Keywords: Self Evaluation, EMI, Character, Favorite School

\section{Introduction}

Every school would want to be a superior school. To become a superior school requires cooperation and commitment from all stakeholders. Many efforts can be done by schools to form a superior school. One of them is by doing a self evaluation.

School self-evaluation (EDS) is an evaluation of the school's success in achieving national education standards. EDS is very important to identify weaknesses or non-achievement of targets that the school wants. Also, through EDS, schools can define specific and focused improvement plans. The EDS applied in this research is the EDS Model EMI. This EDS has been applied in LPTK. EDS Model EMI was easy to use and able to provide accurate results. 


\section{Result and discussion}

\subsection{Favorite School Character}

The character of a good school is an effective school or an excellent school [1]. To know the good school used two approach model, that is approach model of goal achievement and process approach model [2]. The goal-achievement model suggests that a good school is a school that achieves all established goals, while the process approach model considers that a good school is a school that has internal consistency, efficient use of the budget, and success in its working mechanism.

According to Danim[3] the criteria of school effectiveness or excellence are (1) having a high and clear working standard; (2) encouraging activity, multicultural understanding, gender equality, and developing learning according to the potential standards of learners; (3) expecting students to take on the roles of responsibility in learning and behaving; (4) having evaluation and assessment instruments of learning achievement, (5) using learning methods based on educational research and professional practice; (6) organizing schools and classes to create environments to support learning activities; (7) making decisions in a democratic and accountable manner; (8) create a sense of security, respect for each other, and effectively accommodate the environment; (9) gives high expectations to all staff; (10) involving families in helping students to achieve success; and (11) working with communities and other parties.

On the other hand, Suyanto [4] asserts that superior schools have certain characteristics: (1) having a strong academic culture; (2) have a curriculum relevant to the development of science and technology; (3) have a school community that creates innovative learning techniques; (4) have an orientation on the development of hard knowledge and soft knowledge in a balanced way; (5) developing students' potential holistically in learning; and (6) developing students' competence and competence in communicating globally.

Meanwhile, based on research, Lezotte [5] concluded the characteristics of superior schools are (1) safe and orderly school environment; (2) high climate and expectation; (3) logical instructional leadership; (4) clear and focused mission; (5) opportunities to learn and do assignments for students; and (6) frequent monitoring of student progress, and supportive home-school relationships. As for Austin (in Moedjiarto, 2002), based on his research found nine characteristics of superior schools: (1) strong instructional leadership; (2) good program development; (3) high performance expectations; (4) the belief that all students can learn basic skills; (5) a positive climate; (6) supervision of school functions, curriculum and staff development programs; (7) strong staff support; (8) encouragement; and (9) high student responsibility and participation.

Based on the opinions and research results above it can be concluded that the characteristics of a superior school is a positive school climate[6] [7], school planning process involving all school residents, high academic achievement expectations, effective student progress monitoring, effective teacher learning, instructional leadership oriented on academic achievement, parent involvement in school activities, opportunities, active responsibilities, high student participation in schools, rewards and incentives based on success, order and discipline, as well as a clear curriculum implementation[8].

To be able to realize a superior school, the school must have clear and measurable planning so that it meets the targeted standards. The plan includes short-term and long-term planning. Short-term planning is planning that its implementation is carried out for the next one year, while long-term planning is planning that execution is done more than one year. For that purpose, planning should be well structured, taking into account the achievements and 
targets. If there is no target achievement, it is necessary to find the root of the problem, whereas if the target is reached or exceeded it is necessary to find the supporting factor. Based on the root of the problem and the supporting factors are set improvement plan and its target. To meet these demands, self-evaluation is required.

\subsection{School Self Evaluation}

School self-evaluation (EDS) in English called School Self Evaluation (SSE) is the process of school responsibility in evaluating progress and encouraging schools to set priorities for school quality improvement [9]. In this sense, there are three things to note, namely

- School responsibility, meaning that EDS filling is the responsibility of the school consisting of principals, teachers, education personnel, students, and school committees;

- Evaluation of progress, meaning that EDS results should be able to photograph the success achieved by the school at this time, i.e. one year ago;

- Improvement in quality, meaning that the results of EDS become the basis for determining quality improvement priorities in subsequent years.

In "Teaching Materials and Training Materials in the Strengthening Capabilities of School Principals / Madrasahs" explained that EDS is an internal evaluation conducted by all stakeholders of education to know thoroughly the performance of schools seen from the achievement of minimum service standards (SPM) and eight standards national education (SNP) as well as knowing its strengths and weaknesses so as to obtain input and a real basis for making RPS / RKS in an effort to foster a culture of continuous quality improvement [10].

From this understanding, there are some things to note in the EDS, ie

- Internal evaluation, meaning that evaluations are made by facts that exist in the school and conducted by the internal school;

- Stakeholders, meaning that the self-evaluation should be all stakeholders, including principals, teachers, education personnel, students, and school committees;

- $\quad$ school performance, meaning that self-evaluation is useful as a tool to measure school performance on the achievement of SPM and SNP;

- SPM and SNP, meaning that the basis of self-evaluation is a standard achievement to meet minimum service standards and national education standards;

- Strengths and weaknesses, meaning that in self-evaluation is emphasized on how much strength and weakness of school in fulfilling SPM and SNP;

- RPS / RKS, meaning that the results of self-evaluation are used as the basis for preparing the school program plan or school work plan;

- Quality culture, meaning that EDS is done to establish a culture of quality.

Hendarman [11] discloses that self-evaluation is intended as a school mapping process conducted by the principal in an honest and transparent manner so that the root causes of quality education are formulated in recommendations and concrete steps. From that definition it should be noted that EDS should be done honestly and transparently, meaning that in EDS it is not justified to manipulate or manipulate data so that it is produced as it is. Also, in the EDS must be sought the root of the problem so that the follow-up plan is right on target.

Furthermore, in the "Principal Enhancement of Principal Enhancement in Managing Curriculum Implementation: School Self-Evaluation" [10] it is proposed that EDS is an internal school self-evaluation process by involving stakeholders to find out school 
performance based on MSS and SNP and to be basic preparation of RKS and inputs in education investment planning at the district/city level and other stakeholders.

\subsection{Obstacles to School Self Evaluation}

The government, in this case, Kemendikbud, has socialized and conducted EDS online. However, the results have not been maximized. Several research results show the constraints and weaknesses of EDS online so that the results have not met expectations. The results of the research are Fitri Ning Tyas and Desi Nurhikmahyanti[9]; Hendarman[12]; Muhammad Mauluddin and Amy Yayuk Sri Rahayu[11]. Fitri Ning Tyas and Desi Nurhikmahyanti [9]concluded that inhibiting factors of EDS implementation internally include saturation of instruments, lack of teacher understanding, and short time; while externally covering changes to EDS systems and instruments and the number of question items.

Meanwhile, research conducted by Hendarman entitled "School Self-Evaluation Obstacles (EDS)" concluded that the constraints faced in the preparation of EDS include aspects of concepts, instruments, infrastructure, human resources, and administration. The constraints caused by socialization have not been done correctly, school commitments have not existed, and cooperation between stakeholders does not exist yet.

On the other hand, research conducted by Muhammad Mauluddin and Amy Yayuk Sri Rahayu under the title "Analysis of the Implementation of Education Quality Assurance System (SPMP) through School Self-Evaluation (EDS) at SDN Cilandak Timur 08 Pagi South Jakarta" concluded that the implementation of SPMP in SDN Cilandak East 08 Pagi South Jakarta is not in accordance with the instructions. This is due to the weakness of the ability to use IT, lack of budget, lack of time of filling, lack of coordination and cooperation between parties, and the lack of relevance of EDS instruments.

The pre-survey conducted by Nuchron, Sunarto, and F.X. Sudarsono pointed out that in the preparation of EDS there are still many things that must be improved and addressed, ie

- The lack of self-evaluation culture, there are still less commitment, not honest, and open leadership in disclosing facts;

- The Self Evaluation Guidebook is less flexible and elusive;

- Instruments not by very complex developmental conditions;

- Data analysis does not take into account the importance of each component and item on the indicator;

- The self-evaluation guide is not included in the business steps to take corrective action so that there is no solution to solving the self-evaluation result.

Ni Putu Rastiti's research entitled "Online School Self-Evaluation of Self-Evaluation Instrument Practices At SDN No 3 Banjarangkan Klungkung District" concluded that inhibiting factors affecting online EDS charging results include lack of adequate support facilities, lack of computer skills, understanding of EDS and National Education Standards (SNP), lack of school commitments implementing EDS, and lack of local government support. As a result, teachers are more motivated to NUPTK than charging EDS instruments online, students have no chance to understand EDS, and the results of online EDS instrument replenishment have not reflected the true school conditions.

\subsection{School Self-Evaluation EMI Model (Internal Quality Evaluation)}

EMI or Evaluation Internal Quality is an internal quality evaluation model developed by the Human Resources Development Agency for Education and Quality Assurance for 
Education Quality Assurance Center (BPSDMP-PMP) which has been implemented in LPTK. EMI is a systemic activity of quality assurance of internal education (internally driven) to oversee the implementation of education by educational institutions themselves continuously (continuous improvement).

EMI is an instrument of self-evaluation that will be reviewed periodically, tailored to the internal conditions of the school, Indonesia's good practices, national demands, and international developments, by opening up development opportunities by alternative evolving evaluation models dynamic.

Based on the above understanding, primary school EMI can be interpreted as an internal systemic activity by the school to ensure continuous quality assurance that will be reviewed periodically, tailored to the internal conditions of the school, good practices prevailing in Indonesia, national demands, and developments in the world international.

According to Prof. Moses Laksono Singgih in "LPI's EMI Filling Guide," the purpose of EMI preparation are

- To assist agencies and governments establish development programs towards the fulfillment of SNPs;

- Develop a culture of quality; and

- Preparing external evaluation material both nationally and internationally.

In addition, EMI is also aiming for

- Ensuring the suitability of the quality documents to the established standards;

- Ensuring the suitability of the institution's activities with the established quality procedures;

- Knowing the achievement of targets set by the institution;

- Ensuring the effectiveness of system implementation;

- Providing input as a continuous improvement effort

The EMI filling principle as set forth in the "LPI EMI Filling Guide" includes

- Self-assessment, meaning that EMI filling is done from, by, and for the institution concerned;

- Objective and honest means EMI filling is based on data as is or factual facts based on data;

- Internal, EMI filling results are not published to the public, but only as a reference in the development and formulation of institutional policies;

- Continuous, meaning that EMI filling is done continuously every year to know the performance or quality achieved by the institution;

- Anticipative, meaning that EMI filling is done in anticipation of preparation of external evaluation, either by the government (accreditation) or other parties who need at any time

\subsection{Implementation of EMI Model EDS to Build School Character}

EDS The EMI model is a self-assessment developed to assist school stakeholders in identifying the root causes of the inadequacy of school targets so that improvement plans are targeted and more specific in addressing the weaknesses. A proper follow-up plan will increase the achievement of the target so that the national standard of primary school is achieved. On the other hand, EDS Model EMI helps speed up the availability of evaluation documents. In other words, through the EDS Model EMI schools have the advantage in building a superior school character. 
In the book Increasing Principal Competence in Managing Curriculum Implementation it was suggested that the benefits of EDS for schools are

- Identifying advantages and disadvantages to plan future development and upgrading;

- Have accurate baseline data as a basis for future development and quality improvement;

- Identifying the strengths and opportunities to improve the quality of education, the accuracy of quality improvement initiatives, the suitability of the program and its outcomes;

- Present an official report to the external authorities in a responsible manner.

As for the government and external parties, the benefits of EDS are

- To provide data and information necessary for planning, policy-making, preparation of budget plans;

- Identifying the priority needs of educational advice and infrastructure;

- Identify the type of supporting the school needs;

- Identify training needs and other development programs; and

- To identify success in achieving indicators in accordance with MSS and SNP.

Based on these benefits, the school can prepare short and long term work plan quickly and accurately. Short-term work plans are all activities that will be implemented one year ahead, are urgent, and the policy can be decided directly by the principal, such as socializing the school's vision-mission-goal, sending teachers to attend various training education, implementing light-house rehab. The long-term work plan is activities that will be implemented over one year of future lessons, are developmental, and their policies are dependent and related to external parties, such as the construction of new classrooms, the purchase of new land, the addition of new teachers.

On the other hand, until now there is no single tool that can be used to provide an accurate picture of school target achievement, other than EDS. Through EDS internal and external parties can know the general description of target achievement of SPM and eight SNP accurately accompanied by data and evidence. Thus, EDS results can be used by schools as the basis for making RPS / RKS and improving the quality of schools.

Although there have been several evaluation efforts at school, most of them are evaluations conducted by outsiders, so they are external, to assess schools \&ndash; for accreditation, grants etc. Thus the presence of EDS is needed by the school because it is an internal evaluation conducted by and for the school itself to know its own strengths and weaknesses \&ndash; a kind of face mirror that can be used in view of its own strengths and weaknesses for subsequent basic use in an effort to improve its performance.

EDS results can also be used by Supervisors to report to the District Education Office / Kemenag Office of the city/city through activities of "Monitoring Schools by Local Government" (MSPD) as input for the basis of the Quality Improvement Planning and the baseline of assistance/intervention to school schools.

\section{Conclusion}

Based on the above description can be concluded

a. Each elementary school has a responsibility to build a character of excellence for all stakeholders; 
b. Building the character of primary school excellence should be carefully planned in the form of short-term plans and long-term plans;

c. To produce an accurate work plan it requires an internal self-evaluation of schools that describes the school's attainment of Junior High School and SNP;

d. EDS Model EMI is one type of EDS that can be done easily, quickly, and accurately;

e. With EDS Model EMI primary school will be able to perform routinely in the preparation of EDS so that the goal to become a school of excellence character will be achieved.

\section{References}

[1] T. J. et al. Sergiovanni, Educational Governance and Administration. New Jersey: Prentice Hall Inc., 1987.

[2] W. K. Hoy and J. Ferguson, "A Theoretical Framework and Exploration of Organizational Effectiveness of Schools," Educ. Adm. Q., vol. 21, no. 2, pp. 117-134, May 1985.

[3] S. Danim, Visi Baru Manajemen Sekolah, Dari Unit Birokrasi ke Lembaga Akademik. Jakarta: Bumi Aksara, 2006.

[4] H. S. Elfahmi, "Sekolah Unggul: Menciptakan Sekolah sebagai Sumber Solusi dan Rumah yang Menyenangkan bagi Setiap Penghuninya," in National Congress \& Business Forum, 2006.

[5] L. W. Lezotte and B. A. Bancroft, "School Improvement Based on Effective Schools Research: A Promising Approach for Economically Disadvantaged and Minority Students," J. Negro Educ., vol. 54, no. 3, p. 301, 1985.

[6] D. Ibnu Aqil, "Building Religious Characters Through a Biological Perspective," AlHayat J. Islam. Educ., vol. 2, no. 2, pp. 1-10, 2018.

[7] M. Suriadi Samsuri, Mursidin, "Character Education Based on Gender Justice in The Islamic Perspective," Al-Hayat J. Islam. Educ., vol. 2, no. 2, pp. 202-212, 2018.

[8] A. Ikhwan, Pengembangan Kurikulum Pendidikan Agama Islam (PAI). Malang: Insan Cita Press dan STAIM Tulungagung, 2013.

[9] F. N. Tyas and D. Nurhikmahyanti, "Penerapan Program Evaluasi Diri Sekolah (EDS) (Studi Kasus Di SMA Negeri 1 Gresik)," J. Inspirasi Manaj. Pendidik., vol. 3, no. 3, pp. 89-99, Sep. 2014.

[10] N. Nuchron, S. Soenarto, and F. X. Sudarsono, "Model evaluasi diri sekolah menengah kejuruan di Daerah Isitimewa Yogyakarta," J. Pendidik. Vokasi, vol. 3, no. 1, Feb. 2013.

[11] M. Mauluddin and A. Y. S. Rahayu, "Analisis Pelaksanaan Sistem Penjaminan Mutu Pendidikan (SPMP) Melalui Evaluasi Diri Sekolah (EDS) di SDN Cilandak Timur 08 Pagi Jakarta," 2016.

[12] H. Hendarman, "Kendala-Kendala Pelaksanaan Evaluasi Diri Sekolah (EDS)," J. Pendidik. dan Kebud., vol. 20, no. 1, pp. 74-85, 2014. 